\title{
ANALISISPENGARUHMANAJEMENLABA TERHADAPRETURNSAHAMPADA PERUSAHAAN PERTAMBANGANDAN PERUSAHAAN MANUFAKTUR DI BURSA EFEK INDONESIA
}

\author{
Mokhamad Syaifudin Zuhri \\ Nasharuddin Mas \\ mokhamadudin@yahoo.com
}

\begin{abstract}
Abstrak: Tujuan penelitian ini Program Pascasarjana Universitas Widyagama Malang adalah untuk menganalisis pengaruh manajemen laba terhadap return saham pada perusahaan pertambangan dan perusahaan manufaktur yang go public di Bursa Efek Indonesia dan untuk menganalisi sperbedaan antara return pada perusahaan pertambangan dan perusahaan manufaktur di BEI.

Sampel penelitian ini sebanyak 29 perusahaan, terdiri 6 perusahaan pertambangan dan 23 perusahaan manufaktur yang go publik di Bursa Efek Indonesia, dengan metode pooling data (2012-2014), sehingga jumlahsampel $(n)=87$. Pengambilan sampel menggunakan metode purposive sampling yaitu pengambilan sampel dengan kriteriakriteria yang ditetapkan.

Hasil penelitian bahwa secara parsial (individu) tidak terdapat pengaruh yang signifikan manajemen laba terhadap return saham, baik perusahaan pertambangan dan perusahaan manufaktur. Hal ini mengindikasikan bahwa besar kecilnya manajemen laba yang dilakukan pihak manajemen perusahaan tidak berpengaruh signifikan pada kenaikan return saham perusahaan. Pada uji chowtes $\mathrm{t}$ diperoleh nilai $\mathrm{F}$ hitung sebesar 12,10 lebih besar dibandingkan $\mathrm{F}$ tabel taraf signifikansi 5\% sebesar 7,88 sehingga diperoleh hasil ada perbedaan yang signifikan return saham perusahaan pertambangan dan perusahaan manufaktur. Kecenderungan tindakan manajemen laba (rata-rata nilai diskresionerakrual) pada perusahaan pertambangan sebesar 0,0040 sedangkan tindakan manajemen laba (rata-rata nilai diskresionerakrual) pada perusahaan manufaktur sebesar 0,0058 yang menunjukkan bahwa perusahaan pertambangan lebih kecil kecenderungan melakukan manajemen laba dibandingkan dengan perusahaan manufaktur.
\end{abstract}

Kata Kunci: Manajemen Laba, Return Saham, Pertambangan, Manufaktur

Abstract: The purpose of this study is to analyze the effect of earnings management on stock returns on mining companies and manufacturing companies that go public in Indonesia Stock Exchange and to analyze the difference between return on mining companies and manufacturing companies in BEI.The sample of this research is 29 companies, consisting of 6 mining companies and 23 manufacturing companies that go public in Indonesia Stock Exchange, by pooling data method (2012-2014), so the samples $(n)=87$. Sampling using purposive sampling method is sample with defined criteria.The result of research that partially (individual) there is no significant effect of earnings management to stock return, both mining company and manufacturing company. This indicates that the size of earnings management conducted by the management company has no significant effect on the increase of stock return of the company. In chowtes $t$ test obtained the value of $F$ arithmetic of 12.10 is greater than $F$ table significance level of 5\% of 7.88 so obtained results there is a significant difference 
stock return mining companies and manufacturing companies. The tendency of earnings management action (average discretionaryakrual value) in a mining company amounted to 0.0040 while the earnings management (average discretionaryakrual value) on manufacturing firms was 0.0058 indicating that mining companies were less likely to earn earnings management than firms manufacture.

Keywords:Earning Management, Stock Return, Mining, Manufacturing

Saat ini, manajemen laba merupakan isu sentral yang terus diperdebatkan. Beberapa periode yang lalu mungkin kita masih asing mendengar istilah manajemen laba, namun sekarang praktik manajemen laba ini seperti sudah menjadi sebuah fenomena umum yang terjadi pada perusahaan di seluruh dunia. Meskipun belum diketahui secara pasti apakah tindakan manajemen laba itu legal atau tidak, beberapa pihak berpendapat bahwa praktik manajemen laba dapat menjadi cikal bakal munculnya tindakan korupsi, fraud, dan tindakan penyelewengan lainnya yang dapat merugikan publik atau pemakai informasi keuangan. Akibatnya dapat merusak tatanan ekonomi, etika, dan moral perusahaan bahkan suatu negara.

Auditing dapat mengurangi asimerti informasi yang ada antara manajemen dan stakeholders perusahaan dengan memungkinkan pihak di luar perusahaan untuk memverifikasi validitas laporan keuangan. Hubungan antara auditing dengan manajemen laba lebih difokuskan pada sisi kualitas auditor yang dikaitkan dengan efektifitas auditing dan kemampuannya untuk mencegah manajemen laba. Publik percaya bahwa auditor berkualitas tinggi (high-quality- auditor) lebih mempunyai kemampuan untuk mendeteksi praktik-praktik akuntansi yang mencurigakan sehingga merupakan pencegahan manajemen laba yang efektif. Hal ini dikarenakan reputasi manajemen akan hancur dan nilai perusahaan akan turun apabila pelaporan yang salah (misreporting) ini terdeteksi dan terungkap.

Peluang untuk mencapai laba tersebut timbul karena metode akuntansi memberikan peluang bagi manajemen untuk mencatat suatu fakta tertentu dengan cara yang berbeda dan peluang bagi manajemen untuk melibatkan subyektivitas dalam menyusun estimasi (Worthy, 1984 Saputro dan Setiawati, 2004). Isu bagaimana pasar modal memproses informasi akuntansi, terutama laba dan komponennya, merupakan hal yang penting bagi partisipan pasar modal. Subramanyam (1996) Ardiati (2005) menemukan bahwa diskresioner total akrual (discretionary accruals) berhubungan dengan harga saham, laba yang akan datang dan aliran kas sehingga manajer memilih akrual untuk meningkatkan keinformatifan (informativeness) laba akuntansi. Disamping itu, akrual memungkinkan manajer mengkomunikasikan informasi privat mereka dan oleh karena itu meningkatkan kemampuan laba untuk mencerminkan nilai ekonomis perusahaan.

Peran akrual sebagai ukuran ringkas kinerja perusahaan menjadi pertanyaan penting dalam riset akuntansi. Laba akrual dipandang sebagai ukuran kinerja perusahaan yang lebih superior daripada aliran kas karena akrual mengurangi masalah waktu dan ketidakcocokan (mismatching) yang melekat dalam pengukuran aliran kas. Kebijakan manajerial dapat meningkatkan keinformatifan laba dengan 
memberikan informasi khusus. Di samping itu, adanya ketidaksepakatan antara manajer dan pemegang saham mendorong manajer untuk menggunakan fleksibilitas yang diberikan untuk mengukur laba secara oportunistik yang menyebabkan distorsi atas laba yang dilaporkan (Watts dan Zimmerman, 1986 Ardiati, 2005).

Menurut Robert Ang (1997: 97) konsep return (kembalian) adalah tingkat keuntungan yang dinikmati oleh pemodal atas suatu investasi yang dilakukannya. Para pemodal tentunya termotivasi untuk melakukan investasi pada suatu instrumen yang diinginkan dengan harapan untuk mendapatkan kembalian investasi yang sesuai. Return (kembalian) adalah tingkat keuntungan yang dinikmati oleh pemodal atas suatu investasi yang dilakukannya. Tanpa adanya keuntungan yang dapat dinikmati dari suatu investasi, tentunya pemodal tidak akan mau repot-repot melakukan investasi, yang pada akhirnya tidak ada hasilnya. Jadi jelas, setiap investasi baik jangka pendek maupun jangka panjang mempunyai tujuan utama mendapatkan keuntungan yang disebut return, baik secara langsung maupun tidak langsung. Manajer mempunyai dorongan untuk mengatur laba untuk memaksimalkan kesejahteraan perusahaan. Dorongan ini tercipta oleh kontrak yang secara eksplisit maupun implisit didasarkan pada laba yang dilaporkan dan berbagai macam situasi dimana laba yang dilaporkan mempunyai peran penting. Sebagian besar penelitian antara lain dilakukan oleh Subramanyam (1996) dan Krishnan (2002) mengenai manajemen laba memfokuskan pada dorongan ini dan mengasumsikan bahwa kemampuan manajemen untuk membuat penyesuaian akuntansi untuk alasan oportunistik sama antar perusahaan. Namun yang terjadi tidak seperti asumsi tersebut. Faktor-faktor yang membedakan antar perusahaan dan membatasi kemampuan manajemen untuk mengatur laba meliputi struktur internal governance perusahaan dan keputusan akuntansi tahun sebelumnya yang dibuat oleh perusahaan yang membatasi pilihan-pilihan akuntansi mendatang (Dechow, 1995 Ardiati, 2005).

Oleh karena itu, penelitian ini bertujuan untuk memberikan bukti empiris apakah pengaruh diskresioner total akrual terhadap return saham lebih besar untuk perusahaan pertambangan dibandingkan dengan perusahaan manufaktur sehingga dapat diketahui perusahaan mana dengan manajemen laba yang memperoleh return saham lebih besar.

Penelitian yang dilakukan oleh Mediastuty dan Machfoedz (2003) dengan obyek penelitian yaitu perusahaan yang go publik yang bukan termasuk kelompok perbankan dan asuransi dengan periode penelitian tahun 1995 - 2000. Hasil penelitian menunjukkan bahwa kepemilikan manajerial dan kepemilikan institusional berhubungan negatif terhadap manajemen laba. Sedangkan ukuran dewan direksi berpengaruh positif dengan manajemen laba.

Penelitian yang dilakukan oleh Meutia (2004) yang menguji hubungan antara kualitas audit dengan manajemen laba, sekaligus melihat pengaruh independensi yang diukur dengan non audit services dan masa jabatan auditor terhadap hubungan antara keduanya. Penelitian ini menemukan bahwa semakin tinggi kualitas audit akan semakin rendah absolute discretionary accruals yang terjadi di suatu perusahaan. Berkaitan dengan pengaruh non audit services ditemukan bahwa non audit service memberi pengaruh antara kualitas audit dengan manajemen laba melalui meningkatnya absolute discretionary accruals pada tahun perusahaan yang menerima 
audit services. Selain itu, berkaitan dengan masa jabatan auditor, hasil temuan ini mendukung pendapat yang menyatakan bahwa semakin tinggi masa jabatan auditor akan lebih meningkatkan kualitas audit karena memberikan kesempatan pada auditor untuk lebih mengenali transaksi kliennya. Penelitian yang dilakukan oleh Sylvia dan Utama (2005) dengan hasil pengujian yang dilakukannya ditemukan bahwa variabel ukuran perusahaan secara konsisten mempunyai pengaruh negatif yang signifikan terhadap besarnya pengelolaan laba yang dilakukan perusahaan, artinya semakin besar ukuran perusahaan maka akan semakin rendah kemungkinan dilakukannya pengelolaan laba perusahaan. Selain itu, rata-rata pengelolaan laba pada perusahaan dengan kepemilikan saham yang tinggi dan bukan perusahaan konglomerasi secara signifikan lebih tinggi dibandingkan rata-rata pengelolaan laba pada perusahaan lain.

Penelitian lainnya dilakukan oleh Gideon (2005) dengan hasil penelitian menunjukkan bahwa pengaruh mekanisme corporate governance, dalam hal ini kepemilikan institusional, kepemilikan manajerial dan komposisi dewan komisaris secara bersama-sama terhadap manajemen laba, teruji dengan tingkat pengaruhnya lemah. Mekanisme kepemilikan institusional memberikan pengaruh terhadap manajemen laba yang cukup kuat. Pengaruh mekanisme corporate governance dan manajemen laba secara bersama-sama terhadap kualitas laba, teruji dengan tingkat pengaruh yang cukup kuat. Kepemilikan institusional memberikan pengaruh terhadap kualitas laba yang lemah. Kepemilikan manajerial memberikan pengaruh terhadap kualitas laba yang lemah. Komposisi dewan komisaris memberikan pengaruh terhadap kualitas laba yang lemah. Dan manajemen laba memberikan pengaruh terhadap kualitas laba yang sangat lemah.

Penelitian yang dilakukan Pudjiastuti dan Mardiyah (2006) dengan hasil penelitian diperoleh bahwa kualitas laba perusahaan tidak berpengaruh terhadap manajemen laba perusahaan. Penelitian yang dilakukan Bangun dan Safei (2006) dengan judul "Pengaruh Manajemen Laba Terhadap Return Saham Pada Perusahaan Yang Diaudit Oleh Kantor Akuntan Publik (KAP) Big Four dan Non Big Four" hasil penelitian diperoleh bahwa perusahaan yang diaudit oleh Kantor Akuntan Publik (KAP) Big Four, hasil uji t variabel akrual diskresioner mempunyai nilai signifikansi sebesar 0,010. Nilai tersebut kurang dari 0,05, maka Hal diterima. Hal ini berarti bahwa secara parsial ada pengaruh yang signifikan antara menajemen laba terhadap return saham. Hasil koefisien menunjukkan nilai negatif $(-1,062)$ berarti variabel bebas yaitu akrual diskresioner mempunyai pengaruh yang arahnya negatif (berbanding lurus) dengan variabel terikatnya yang berupa Return saham.

Pada perusahaan yang diaudit oleh Kantor Akuntan Publik (KAP) Non Big Four, hasil uji t variabel akrual diskresioner mempunyai nilai signifikansi sebesar 0,016. Nilai signifikansi tersebut kurang dari 0,05, maka Ha2 diterima. Hal ini berarti bahwa secara parsial ada pengaruh yang signifikan antara manajemen laba terhadap return saham. Hasil uji $\mathrm{F}$ pada perusahaan yang diaudit oleh KAP Big Four menunjukkan nilai signifikansi sebesar 0,033, sedangkan signifikansi pada perusahaan yang diaudit oleh KAP Non Big Four sebesar 0,044. Kedua nilai signifikansi tersebut kurang dari 0,05, maka Hal diterima. Artinya secara simultan terdapat pengaruh yang signifikan antara manajemen laba sebagai variabel bebas terhadap return saham sebagai variabel terikat 
pada perusahaan yang diaudit oleh Kantor Akuntan Publik (KAP) Big Four maupun Non Big Four dengan tingkat keyakinan $95 \%$. Hasil pengujian ini selaras dengan hasil pengujian yang dilakukan oleh Ardiati (2005) bahwa secara parsial maupun simultan terdapat pengaruh yang signifikan antara manajemen laba terhadap return saham pada perusahaan yang diaudit oleh KAP Big four maupun Non Big Four walaupun arah pengaruhnya berlawanan. Hal ini menunjukkan bahwa KAP Big Four lebih berkualitas dalam mendeteksi terjadinya praktek manajemen laba dalam perusahaan. Dengan demikian pengauditan yang dilakukan oleh auditor berkualitas dapat digunakan untuk meningkatkan kredibilitas laporan keuangan. Pengaruh yang arahnya positif pada perusahaan yang diaudit oleh KAP Non Big Four berarti auditor berkualitas auditor berkualitas rendah kurang mampu mendeteksi adanya praktek manajemen laba yang kemudian berpengaruh terhadap return saham perusahaan.

Penelitian yang dilakukan Andini (2013) dengan hasil penelitian diperoleh bahwa kepemilikan manajerial berpengaruh positif tidak signifikan terhadap pengungkapan tanggung jawab sosial pada perusahaan manufaktur dan perusahaan pertambangan yang tercatat di Bursa Efek Indonesia, artinya manajer belum dapat memaksimalkan nilai perusahaan melalui pengungkapan CSR. Hal ini mungkin saja karena secara statistik rata-rata jumlah kepemilikan saham manajerial pada perusahaan di Indonesia relatif kecil sehingga belum terdapat keselarasan kepentingan antara pemilik dan manajer.

Dari hasil penelitian di atas dapat disimpulkan bahwa penelitian yang dilakukan Ardiati (2005) diperoleh hasil yaitu manajemen laba berpengaruh positif terhadap return pada perusahaan yang diaudit oleh Kantor Akuntan Publik Berskala Besar. Begitu pula dengan penelitian yang dilakukan oleh Halim, Meiden dan Tobing (2005) dengan hasil bahwa return berpengaruh terhadap tingkat pengungkapan laba. Penelitian yang dilakukan oleh Sylvia dan Utama (2005) diperoleh bahwa rata-rata pengelolaan laba (manajemen laba) pada perusahaan dengan kepemilikan tinggi dan bukan perusahaan konglomerasi secara signifikan lebih tinggi dibandingkan rata-rata pengelolaan laba (manajemen laba) pada perusahaan lain. Sedangkan hasil penelitian diperoleh Pudjiastuti dan Mardiyah (2006) belum mampu membuktikan bahwa kualitas laba perusahaan berpengaruh terhadap manajemen laba perusahaan.

Dari hasil-hasil penelitian di atas diperoleh adanya perbedaan hasil penelitian (gap research) yang dilakukan oleh para peneliti. Hal ini akan mengkaji ulang (replikasi) penelitian ini dengan memperbarui periode penelitian mengetahui pengaruh manajemen laba terhadap return saham pada perusahaan pertambangan dan perusahaan manufaktur.

\section{Kerangka Pemikiran}

Pengungkapan manajemen laba merupakan tanggung jawab perusahaan terhadap pihak pihak yang membutuhkan seperti masyarakat pemegang saham, pemerintah, karyawan dan calon investor. Perusahaan mempunyai tanggung jawab moral untuk transparan terhadap manajemen laba terhadap laporan keuangan entitas. Untuk mendeteksi ada tidaknya manajemen laba, maka pengukuran atas akrual adalah hal yang penting untuk diperhatikan. Total akrual adalah selisih antara laba dan 
arus kas yang berasal dari aktivitas operasi. Total akrual dibedakan menjadi dua bagian, yaitu :

(1) bagian akrual yang memang sewajarnya ada dalam proses penyusunan laporan keuangan disebut dengan non discretionary accrual

(2) bagian akrual yang merupakan manipulasi data akuntansi yang disebut discretionary accrual (Utami, 2005).

Para investor termotivasi untuk melakukan investasi pada suatu instrumen yang diinginkan dengan harapan untuk mendapatkan kembalian investasi yang sesuai. Return merupakan hasil yang diperoleh dari investasi atau tingkat keuntungan yang dinikmati oleh investor atas suatu investasi yang dilakukannya (Hartono, 2000:107). Pengaruh manajemen laba terhadap return saham dianalisis untuk mengetahui nilai informasi laporan keuangan perusahaan pertambangan dan perusahaan bagi pasar.

Informasi akuntansi dapat mengurangi konflik kepentingan antara pihak-pihak yang berkepentingan dengan perusahaan (Watts dan Zimmerman, 1990). Pihak-pihak yang berkepentingan tersebut mencakup manajer, investor, kreditor, karyawan, pesaing, pemerintah dan pemasok. Manajemen laba timbul sebagai dampak dari penggunaan akuntansi sebagai salah satu alat komunikasi antara pihak-pihak tersebut dan kelemahan intern akuntansi. Terdapat tiga hipotesis yang berkaitan dengan arti pentingnya output akuntansi, yaitu hipotesis rencana bonus yang menyatakan bahwa manajer perusahaan dengan rencana bonus tertentu lebih menyukai metode yang meningkatkan laba periode berjalan, hipotesis utang atau ekuitas yang menyatakan bahwa makin tinggi rasio utang atau ekuitas perusahaan, makin besar kemungkinan manajer untuk memilih metode akuntansi yang dapat menaikkan laba, hipotesis cost politik menyatakan bahwa perusahaan besar cenderung menggunakan metode akuntansi yang dapat mengurangi laba dibandingkan perusahaan kecil.

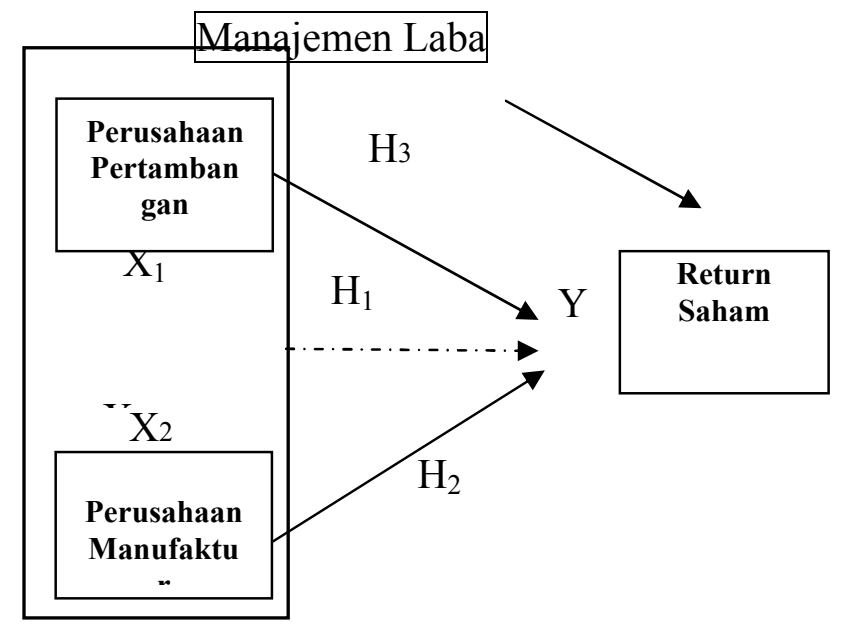

METODE

Penelitian ini menggunakan data sekunder berupa laporan keuangan perusahaan per Desember yang tersedia di BEI tahun 2012- 2014 dan harga saham penutupan tahunan. Data tersebut diperoleh melalui situs yang dimiliki oleh BEI, yakni www.idx.co.id dan Indonesia Capital Market directory (ICMD).Studi pustaka atau 
literatur melalui buku teks, jurnal ilmiah, artikel dan majalah, serta sumber tertulis lainnya yang berkaitan dengan informasi yang dibutuhkan, juga dijadikan sumber pengumpulan data.

Populasi dan Sampel

Populasi dalam penelitian ini adalah perusahaan pertambangan dan perusahaan manufaktur yang go publik dan terdaftar di bursa Efek Indonesia pada tahun 2012 2014. Penelitian ini mengunakan laporan keuangan per 31 Desember 2012 - 2014 sebagai sampel.

Perusahaan yang menjadi sampel dalam penelitian ini adalah perusahaan yang dipilih berdasarkan metode purposive sampling yaitu pengambilan data berdasarkan kriteria-kriteria tertentu. Adapun kriteria- kriterianya yaitu perusahaan pertambangan dan perusahaan manufaktur di BEI yang mempunyai laba bersih selama 3 tahun berturut-turut periode 2012 - 2014, penyajian laporan keuangan dalam mata uang rupiah, dan perusahaan yang akhir periode akuntansinya jatuh pada 31 Desember.

Observasi dilakukan pada 192 perusahaan manufaktur dan 19 perusahaan pertambangan di BEI selama 3 (tiga) tahun berturut-turut dari tahun 2012 sampai dengan tahun 2014 dengan tabel sebagai berikut :

\section{Teknik Analisis Data}

\section{Statistik Diskriptif}

Statistik diskriptif digunakan untuk mengetahui nilai rata- rata (mean), distribusi frekuensi, nilai minimum dan maksimum, serta deviasi standar. Statistik diskriptif akan dilakukan pada data karakteristik perusahaan (diskresioner total akrual dan return saham). Data yang diteliti akan dikelompokkan menjadi dua kelompok sampel, yaitu Perusahaan Pertambangan dan Perusahaan Manufaktur.

\section{Uji Hipotesis}

a. (H1) Uji Hipotesis Pertama: Manajemen laba berpengaruh signifikan dan positif terhadap return saham pada perusahaan pertambangan dan perusahaan manufaktur yang go public di BEI

Untuk menganalisis pengaruh antara variabel bebas terhadap variabel terikat, maka digunakan analisis regresi sederhana. Analisis regresi sederhana digunakan untuk mengetahui bagaimana variabel bebas dapat mempengaruhi variabel dependennya dengan rumus:

$$
\mathrm{Y}=\mathrm{bo}+\mathrm{bX}+\mathrm{e}
$$

Keterangan notasi:

$\mathrm{Y}=$ variabel Return Saham

$\mathrm{X}=$ variabel Manajemen Laba

$\mathrm{e}=$ residual error

$\mathrm{b}=$ koefisien garis regresi

Pengujian hipotesis secara parsial (individual) dilakukan dengan uji t. Tujuan penggunaan uji $t$ adalah untuk mengetahui seberapa jauh pengaruh masing-masing 
variabel-variabel bebas terhadap variabel terikatnya secara parsial. Hipotesis yang diuji adalah :

a. Ho : $\beta 1=0$; berarti tidak ada pengaruh yang signifikan antara variabel Manajemen Laba terhadap Return Saham secara parsial (individu)

b. Ha : $\beta 1 \neq 0$; berarti ada pengaruh yang signifikan antara variabel Manajemen Laba terhadap Saham Return secara parsial (individu)

c. Apabila t hitung $>t$ tabel ; maka Ho diterima (ada pengaruh yang signifikan).

\section{HASIL}

Berdasarkan hasil pengujian, pengaruh Manajemen Laba (X) terhadap Return Saham $(\mathrm{Y})$, didapatkan angka t-hitung sebesar $0,475<\mathrm{t}$ - tabel $(\mathrm{df}=\mathrm{n}-\mathrm{k}=36-1=35 ; \alpha=5 \%$, dua sisi) sebesar 2,0301. Begitu pula dengan angka probabilitas sebesar $0,651>\alpha=5 \%$, hal ini berarti hipotesis Ha ditolak. Oleh karena itu, tidak terdapat pengaruh yang signifikan Manajemen Laba terhadap Return Saham. Hal ini mengindikasikan bahwa besar kecilnya manajemen laba yang dilakukan pihak manajemen perusahaan akan tidak mampu berpengaruh signifikan pada kenaikan return saham perusahaan.

Pengaruh Manajemen Laba terhadap Return Saham pada Perusahaan Manufaktur Berdasarkan perhitungan statistik, maka data manajemen laba yang diproksi dengan non diskresioner akrual, return saham pada perusahaan manufaktur di Bursa Efek Indonesia periode tahun 2012 - 2014 bahwa rata-rata return saham pada perusahaan manufaktur di BEI tahun 2012 - 2014 yang diteliti sebesar 69 dengan angka minimum sebesar -0,81 dan angka maksimum sebesar 6,41.

Data ini menunjukkan bahwa rata-rata keuntungan atas penjualan tiap lembar saham perusahaan manufaktur periode tahun 2012 - 2014 sebesar 0,2185. Rata-rata manajemen laba yang diproksi dengan diskresioner total akrual pada perusahaan manufaktur di BEI tahun 2012 - 2014 yang diteliti sebesar 69 dengan angka minimum sebesar $-0,47$ dan angka maksimum sebesar 1,49. Data ini menunjukkan bahwa rata-rata manajemen laba pada perusahaan manufaktur di BEI yang diaudit oleh tahun $2012-2014$ sebesar 0,0058 .

\section{Pengujian Hipotesis Kedua dan Pembahasan}

Perbedaan return saham pada perusahaan go public pada Perusahaan Pertambangan dan Perusahaan Manufaktur, manakah yang berpengaruh dominan terhadap return sahamPengujian pada hipotesis kedua ini menggunakan uji Chow Test yaitu suatu alat untuk menguji test for equality of coefficients atau uji kesamaan koefisien dan test ini ditemukan oleh Gregory Chow (Imam Ghozali, 2005). Uji ini dilakukan jika hasil observasi yang diteliti terdiri dari 2 kelompok. Hasil pengujian pada observasi total diperoleh nilai restricted residual sum of squares atau RSSr (RSS3) sebesar 94,304 dan df $=177-1=170$. Regresi dengan observasi Perusahaan Pertambangan dan dapatkan nilai restricted residual sum of squares atau RSS1 sebesar 6,045 dengan df ( $\mathrm{n} 1-\mathrm{k}=36-$ $1=35$ ). Dan Regresi dengan observasi Perusahaan Manufaktur dan mendapatkan nilai restricted residual sum of squares atau RSS2 sebesar 88,204 dengan df ( $\mathrm{n} 1-\mathrm{k}=141-1$ $=140)$. 
Penjumlahan antara RSS1 dan RSS2 sebesar 94,249 yang disebut dengan unrestricted residual sum of squares (RSSur) dengan $\mathrm{df}=\mathrm{n} 1+\mathrm{n} 2-2 \mathrm{k}$ sebesar 175 dan diperoleh nilai $\mathrm{F}$ test sebagai berikut :

(RSSr - RSSUr) / k

$\mathrm{F}=(\mathrm{RSSUr} /(\mathrm{n} 1+\mathrm{n} 2-2 \mathrm{k})$

$(94,304-88,204) / 1$

$\mathrm{F}=(88,204 /(175)$

$$
\mathrm{F}=\frac{6.51}{------}=12.10
$$

Hasil tersebut menunjukkan nilai $\mathrm{F}$ hitung sebesar 12,10 sedangkan $\mathrm{F}$ tabel dengan $\mathrm{df} 1=\mathrm{k}=1$ dan $\mathrm{df} 2=\mathrm{n} 1+\mathrm{n} 2-2 \mathrm{k}=175$ sebesar

7,88 yang berarti bahwa model regresi yang dilakukan dalam pengujian pengaruh manajemen laba terhadap return saham pada Perusahaan Pertambangan dan Perusahaan Manufaktur memang berbeda.

Perbedaan antara Perusahaan Pertambangan dan Perusahaan Manufaktur dapat dilihat dengan membandingkan nilai rata-rata diskresioner total akrual (manajemen laba) pada Perusahaan Pertambangan sebesar 0,0031; sedangkan nilai rata-rata diskresioner total akrual (manajemen laba) pada Perusahaan Manufaktur sebesar 0,0049. Dari data tersebut menunjukkan perbedaan yang ada bahwa diskresioner total akrual (manajemen laba) pada Perusahaan Pertambangan lebih rendah dibandingkan dengan Perusahaan Manufaktur.

Begitu pula nilai rata-rata return saham pada Perusahaan Pertambangan sebesar 0,1794; sedangkan nilai rata-rata return saham pada Perusahaan Manufaktur sebesar 0,2185. Dari data tersebut menunjukkan perbedaan yang ada bahwa return saham pada Perusahaan Pertambangan lebih rendah dibandingkan dengan Perusahaan Manufaktur.Berdasarkan uraian diatas antara perusahaan pertambangan dan perusahaan manufaktur yang paling berpengaruh dominan terhadap return saham adalah perusahaan manufaktur.

\section{Pengujian Hipotesis ketiga dan Pembahasan}

Pengaruh Manajemen Laba terhadap Return Saham pada Gabungan Perusahaan Pertambangan dan Perusahaan Manufaktur

\section{Statistik Deskriptif}

Berdasarkan perhitungan statistik, maka data manajemen laba yang diproksi dengan non diskresioner akrual, return saham pada Perusahaan Pertambangan dan Perusahaan Manufaktur di Bursa Efek Indonesia periode tahun 2012 - 2014. Statistik Deskriptif gabungan Perusahaan Pertambangan dan Perusahaan Manufaktur dapat disimpulkan bahwa rata-rata return saham pada Perusahaan Pertambangan dan Perusahaan Manufaktur di BEI tahun 2012 - 2014 sebesar 0,2104 dengan angka minimum sebesar -0,88 dan angka maksimum sebesar 6,34. Data ini menunjukkan bahwa rata-rata keuntungan atas penjualan tiap lembar saham gabungan Perusahaan Pertambangan dan Perusahaan Manufaktur yang Periode tahun 2012 - 2014 sebesar 0,2104 . 
Rata-rata manajemen laba yang diproksi dengan diskresioner total akrual pada Perusahaan Pertambangan dan Perusahaan Manufaktur di BEI tahun 2012 - 2014 sebesar 0,0044 dengan angka minimum sebesar -0,60 dan angka maksimum sebesar 1,36. Data ini menunjukkan bahwa rata-rata manajemen laba pada Perusahaan Pertambangan dan Perusahaan Manufaktur di BEI tahun 2012 - 2014 sebesar 0,0044.

Gabungan Perusahaan Pertambangan dan Perusahaan Manufaktur di BEI tahun 2012 2014 menunjukkan bahwa manajemen laba Perusahaan Pertambangan masih di bawah Gabungan Perusahaan Pertambangan dan Perusahaan Manufaktur yaitu sebesar 0,0040 sedangkan manajemen laba Perusahaan Manufaktur masih diatas Gabungan Perusahaan Pertambangan dan Perusahaan Manufaktur yaitu sebesar 0,0058. Hal ini menggambarkan bahwa merger Perusahaan Pertambangan dan Perusahaan Manufaktur akan mengurangi manajemen laba yang ada di Perusahaan Manufaktur.

\section{SIMPULAN}

a. Secara parsial (individu) tidak terdapat pengaruh yang signifikan manajemen laba terhadap return saham, baik perusahaan pertambangan dan perusahaan manufaktur. Hal ini mengindikasikan bahwa besar kecilnya manajemen laba yang dilakukan pihak manajemen perusahaan tidak berpengaruh signifikan pada kenaikan return saham perusahaan. Hasil penelitian tidak konsisten dengan penelitian yang dilakukan oleh Aloysia Yanti Ardiati (2005) bahwa manajemen laba berpengaruh positif terhadap return saham.

b. Pada uji Chow Test diperoleh nilai F hitung sebesar 12,10 lebih besar dibandingkan $\mathrm{F}$ tabel taraf signifikansi 5\% sebesar 7,88 sehingga diperoleh hasil ada perbedaan yang signifikan return saham pada perusahaan pertambangan dan perusahaan manufaktur. Kecenderungan tindakan manajemen laba (rata-rata nilai diskresioner total akrual) pada perusahaan pertambangan sebesar 0,0031 sedangkan tindakan manajemen laba (rata-rata nilai diskresioner total akrual) pada Perusahaan Manufaktur sebesar 0,0049 yang menunjukkan bahwa perusahaan pertambangan lebih kecil kecenderungannya untuk melakukan manajemen laba dibandingkan dengan perusahaan manufaktur.

c. Berdasarkan hasil pengujian, pengaruh Manajemen Laba (X) terhadap Return Saham (Y) pada Perusahaan Pertambangan dan Perusahaan Manufaktur, didapatkan angka t-hitung sebesar 0,453 $<\mathrm{t}$-tabel $(\mathrm{df}=\mathrm{n}$ - $\mathrm{k}=171-1=170 ; \alpha=5 \%$, dua sisi) sebesar 1,9740. Begitu pula dengan angka probabilitas sebesar $0,651>\alpha=5 \%$, hal ini berarti hipotesis Ha ditolak. Oleh karena itu, tidak terdapat pengaruh yang signifikan Manajemen Laba terhadap Return Saham. Hal ini mengindikasikan bahwa besar kecilnya manajemen laba yang dilakukan pihak manajemen perusahaan akan tidak mampu berpengaruh signifikan pada kenaikan Return saham perusahaan.

\section{Saran}

a. Secara teoritis tindakan perusahaan untuk memanajemen laba akan menyebabkan ketertarikan investor pada suatu perusahaan karena kinerja keuangan perusahaan yang baik. Hal ini mampu berdampak baik pada return saham perusahaan karena banyaknya minat investor yang menanamkan investasi pada perusahaan tersebut meskipun hasil penelitian diperoleh bahwa secara parsial 
(individu) tidak terdapat pengaruh yang signifikan Manajemen Laba terhadap Return Saham. Jadi menurut hemat kami semestinya perusahaan melaksanakan pembuatan laporan keuangan sesuai Standart Akuntansi yang dianutnya tanpa memanipulasi laba.

b. Investor perlu mempertimbangkan kualitas dari suatu corporate baik itu dari perusahaan pertambangan maupun perusahaan manufaktur dan dari uraian diatas dapat disimpulkan bahwa perusahaan pertambangan lebih kecil kemungkinan melakukan manajemen laba dibandingkan dengan perusahaan manufaktur. Hal tersebut memberikan informasi kepada investor dalam menentukan keputusan berinvestasi dipandang dari sisi kualitas suatu corporate terutama pada kedua jenis perusahaan.Oleh karena itu, investor hendaknya lebih mempertimbangkan untuk pengambilan keputusan berinvestasi pada perusahaan pertambangan karena kualitasya lebih baik dan lebih kecil kemungkinan melakukan manajemen laba.

c. Pada hipotesis pertama dan kedua diperoleh hasil bahwa pada perusahaan pertambangan maupun perusahaan manufaktur menunjukkan manajemen laba tidak berpengaruh signifikan terhadap Return Saham. Hasil ini mengindikasikan bahwa besarnya manajemen laba yang dilakukan perusahaan tidak mempengaruhi secara signifikan terhadap fluktuasi (naik turunnya) return saham perusahaan.

d. Pada uraian dan pembuktian dari beberapa penelitian meskipun hasilnya masih belum ada kesamaan tentang manajemen laba apakah menguntungkan bagi corporate atau tidak, dan belum ada aturan yang membolehkan atau melarang manajemen laba, maka penulis menyarankan untuk membuat laporan keuangan sesuai dengan standar akuntansi yang di anut tanpa merekayasa laporan keuangan sesuai dengan keinginan stakeholder atau pemilik.

\section{DAFTAR RUJUKAN}

--, Keputusan Menteri Keuangan Republik Indonesia No 308 Tahun 2002 tentang Komite Standar Akuntansi Pemerintahan.

-_, Keputusan Menteri Keuangan Republik Indonesia No 58 Tahun 2012 tentang Penetapan Politeknik Negeri Malang sebagai Badan Layanan Umum.

-_, Peraturan Direktorat Perbendaharaan No 67 Tahun 2007 tentang perubahan tata cara pengintegrasian Laporan Keuangan BLU kedalam Laporan Keuangan Kementerian Negara / Lembaga.

Aditya Septiani, 2005. Faktor-faktor Yang Mempengaruhi Ketepatan Waktu Pelaporan Keuangan Pada Padar Modal Yang Sedang Berkembang : Perspektif Teori Pengungkapan. Tesis. Universitas Diponegoro. Semarang.

AICPA, Objective of Financial Statement, FSAB, Statement, dalam harahap. 2011. Teori Akuntansi.Jakarta : Raja Grafindo Persada.

Aryani, Farida. 2013. Analisis Faktor-Faktor Yang Mempengaruhi Kualitas Laporan Keuangan Kementerian Negara/Lembaga Satuan Kerja Mitra KPPN Medan II. Tesis. Dipublikasikan. Universitas Sumatera Utara.

Bambang Wahyudi. 2002. Manajemen Sumber Daya Manusia. Bandung. Sulita.

Belkaoui, Ahmed R. 2001. Teori Akuntansi, Edisi 4, Jilid 2. Alih Bahasa Mawinta, Hajayanti Widiastuti, Heri Kurniawan, Alia Arisanti. Penerbit Salemba Empat, 
Jakarta.

Cooper, D.R. dan Emory, C.W. (1995) Business Research Methods. US: Irwin.

Diah Puri S, Bestarii Dwi H. 2015. Analisis Faktor-Faktor Yang mempengaruhi Kualitas Informasi Laporan Keuagnan Pemerintah.Daerah. Jurnal Dinamika Akuntansi Vol 7. No. 2. 139-149. ISSN 2085-4277.Universitas Negeri Semarang.

Erlynda Y. Kasim. 2015. Effect of Goverment Accountants Competency and Implementation of Internal Control to the quality of Goverment Financial Reporting. International journal of business, Ekonomics and Law, Vol. 8, ISSN 2289-1552. Doctoral of Padjajaran University.

Ferdy Van Beest, Geert Braam, and Suzanne Boelens. 2009. Quality of Financial Reporting: Measuring Qualitative Characteristics. Nijmegen Center for Economics (NiCE). Working Paper 09-108. April.

Gujarati, Damodar, 2003. Ekonometri Dasar. Terjemahan : Sumarno Zain, Jakarta : Erlangga.

Hertati, Lesi. 2015. Competence of Human Resources, The Benefits of Information Technology on Value of Financial Reporting in Indonesia. Research Journal of Finance and Accounting. Vol 6. No. 8. STIE Rahmani. Indonesia.

Husein Umar. 2007, Metode Penelitian untuk Skripsi dan Tesis Bisnis, Jakarta: PT. Raja Grafindo Persada

Hutapea, Parulian dan Nurianna Thoha. 2008. Kompetensi Plus. Jakarta: PT. Gramedia Pustaka Utama.

Indriasari, Desi Dan Hertambang. 2008. Pengaruh Kapasitas Sumber Daya Manusia, Pemanfaatan Teknologi Informasi Dan Sistem Pengendalian Intern Terhadap Nilai Informasi Pelaporan Keuangan Pemerintah Daerah.Jurnal SNA. Politeknik Negeri Sriwijaya Palembang

Indriasih, Dewi (2014).2014. The Effect of Goverment Apparatus Competence and the Effectiveness of Goverment Internal Control Toward the Quality of Financial Reporting in Local Goverment. Research Journal of Finance and Accounting Vol.5, No. 20. Padjajaran University-Indonesia

Kadek, Nyoman \& Sinarwati. 2014. Pengaruh Kompetensi SDM, Penerapan SAP, dan Sistem Akuntansi Keuangan Daerah terhadap Kualitas Laporan Keuangan Daerah. E-Journal Volume 2 No: 1) Universitas Pendidikan Ganesha

Keputusan Kepala BKN No 46A Tahun 2003 tentang Pedoman Penyusunan Standar Kompetensi Jabatan Struktural Pegawai Negeri Sipil.

Mardiasmo. 2006. Perwujudan Transparansi dan Akuntabilitas Publik Melalui Akuntansi Sektor Publik: Suatu Sarana Good Governance. Jurnal Akuntansi Pemerintah. Vol. 2 No.1, Hal 1-17.

Mas'ud, Fuad. 2004. Survai Diagnosis Organisasional Konsep \& Aplikasi. Badan Penerbit Universitas Diponegoro.Semarang.

Mashuri. 2008. Penelitian Verifikatif. Edisi Pertama. Yogyakarta: Andi

Masmudi, 2003. Laporan Keuangan Sektor Publik Antara Konsep dan Praktek. Jurnal Akuntansi dan Keuangan Sektor Publik. Volume 3(1).

Mc Daniel. Linda, Roger D Martin and Laureen A. Maines. 2002. Evaluating Financial Reporting Quality. Accounting Review. December 1.

Muins, Sutan Makmur, Standar Kompetensi Tenaga Kerja Indonesia dalam manajemen pembangunan, Nomor 31 Tahun 1X, September 2000. LAN.

Nader Rezaei. 2013. The Effect of Information Technology System on The Accounting 
Information Quality. Journal of Applied Business and Finance Researches.Scienceline Publication. Volume 2 Issu 2:41-49. Islamic Azad University, Bonab, IRAN.

Ni Luh Udiyanti, Atmaja \& Darmawan. 2014. Pengaruh Penerapan Standar Akuntansi Pemerintahan, Sistem Pengendalian Internal, dan Kompetensi Staf Akuntansi Terhadap Kualitas Laporan Keuangan Pemerintah Daerah. Jurnal Akuntansi Volume 2 No. 1. Universitas pendidikan Ganesha.

Nunuy Nur Afiah \& Dien Noviany Rahmatika. 2014. Factors Influencing the quality of financial reporting and its implications on goog goverment governance (Research on local goverment indonesia). Internasional Journal Busines, economic and Law. Vol. 5 ISSN 2289-1552. Padjajaran University

Nurillah (2014). Pengaruh Kompetensi Sumberdaya manusia, pemanfaatan teknologi informasi terhadap kualitas laporan keuangan pemerintah daerah. Skripsi. dipublikasikan.

Nuryanto, Muhammad \& Nunuy nur afiah (2013). The Impact of Apparatus Competence, Information Technology Utilization and Internal Control on Financial Statemen Quality (Study on Local Goverment of Jakarta ProvinceIndonesia). World Review of Business Research. Vol 3 No. 4 pp 157-171. Padjajaran University. Indonesia.

Republik Indonesia, Undang-Undang Nomor 17 Tahun 2003 tentang Keuangan Negara.

Sagara, Yusar. 2015. The Effect of Implementation Accounting Information System and Competence of Human Resources on TheQuality of Financial Reporting. Reserch Journal of Finance and Accounting. Vol 6 No. 10. Padjadjaran University. Indonesia

Sekaran, Uma. 2000. Metode Penelitian Untuk Bisnis. Edisi Keempat. Penerjemah: Kwan Men Yon. Penerbit Salemba Empat. Jakarta.

Setiyawati, hari (2013). The Effect of Internal Accountants' competence, Managers' commitment to Organizations and Implementation of Internal Control System on the Quality of Financial Reporting. Internasional Journal of Business and Managemen Invention. ISSN (Online):2319-8028. Padjadjaran University.Indonesia

Sueb, 2014. Pengaruh Gaya Kepemimpinan terhadap Kualitas Laporan keuangan melalui Sumber Daya Manusia dan Teknologi Informasi sebagai variabel intervening (Studi Kasus pada BLU Institute Teknologi Sepuluh Nopember Surabaya). Thesis. Tidak dipublikasikan

Sugijanto. 2002. Peranan Sistem Akuntansi Pemerintah Pusat Dalam Meningkatkan Akuntabilitas Keuangan dan Implikasi UU No. 22/25 Tahun 1999. Lintasan Ekonomi.Volume XIX Nomor 1.Hal. 50-66.

Sugiyono. 2007. "Metode Penelitian Kuantitatif Kualitatif dan R\&D". Bandung: Alfabeta

Sugiyono. 2008. Metode Penelitian Kuantitatif. Kualitatif dan $R \& D$, Penerbit Alfabeta. Bandung.

Sukmaningrum, T. dan Harto, P. 2011. Analisis Faktor-Faktor yang Mempengaruhi Kualitas Informasi Laporan Keuangan Pemerintah Daerah (Studi Empiris Pada Pemerintah Kabupaten dan Kota Semarang). Tesis. Universitas Diponegoro. Semarang.

Tausikal, Askam. 2007. The Effect of Financial Accounting System Comprehension and 
Local Goverment Financial Managemen on the works units performance of local goverment. Journal of Financial \& Public Sector Accounting.Vol 8 No. 1

Wilkinson. 2000. Sistem Informasi dan informasi. Edisi Kedua Alih Bahasa Marianus Sinaga. Erlangga. Jakarta.

Yosefrinaldi. 2013. Pengaruh Kapasitas Sumber Daya Manusia dan Pemanfaatan Teknologi Informasi Terhadap Kualitas Laporan Keuangan Pemerintah Daerah Dengan Variabel Intervening Sistem Pengendalian Intern Pemerintah (Studi Empiris Pada Dinas Pengelolaan Keuangan dan Aset Daerah Se-Sumatera Barat). Tesis. Fakultas Ekonomi UniversitasNegeriPadang. 